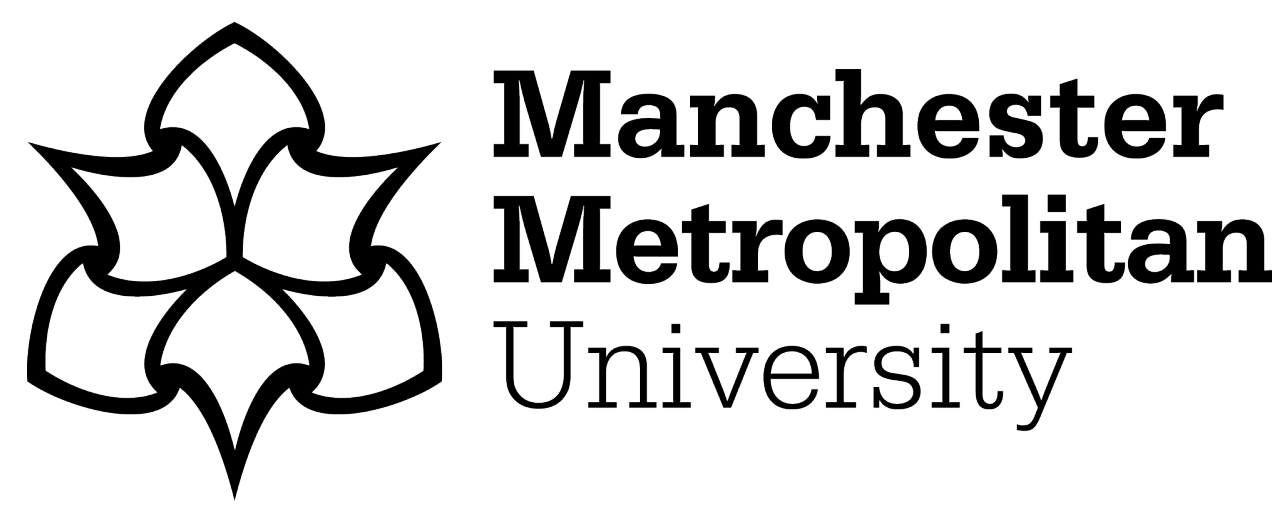

Jacobs, SM ORCID logoORCID: https://orcid.org/0000-0002-5435-3421, Brahic, B ORCID logoORCID: https://orcid.org/0000-0001-9678-8928 and Medusa Olaiya, M (2015) Sexual harassment in an east African agribusiness supply chain. The Economic and Labour Relations Review, 26 (3). pp. 393-410. ISSN 1035-3046

Downloaded from: https: //e-space.mmu.ac.uk/468/

Version: Accepted Version

Publisher: SAGE Publications

DOI: https://doi.org/10.1177/103530461559560

Please cite the published version 


\title{
Sexual harassment in an east African agribusiness supply chain
}

\author{
Susie Jacobs \\ Manchester Metropolitan University \\ Bénédicte Brahic \\ Manchester Metropolitan University \\ with Marta Medusa Olaiya \\ Women Working Worldwide
}

Corresponding author: Dr Susie Jacobs, Manchester Metropolitan University - Sociology, Manton Building, Rosamund Street West, Oxford Road, Manchester M15 6LL United Kingdom. Email: s.jacobs@mmu.ac.uk,

\begin{abstract}
This article discusses sexual harassment in the east African cut-flower and horticultural industry, based on research on 62 farms in Ethiopia, Kenya, Tanzania and Uganda. It argues that sexual harassment is fostered both by coercive labour conditions within global value chains and by existing hierarchical gender relations. The research finds that harassment is widespread; that many lack a vocabulary to describe or discuss this, and that female casual and temporary workers are most likely to be targeted. Action research coupled with organisation of workers, however, has been effective in giving 'voice' to those suffering harassment: this is a first step in a feminist labour mobilisation and policy formulation. Procedures against sexual harassment are beginning to be formulated: a key concern is implementation. Addressing sexual harassment is central in ensuring the security of working people, particularly the most marginalised. ${ }^{l}$
\end{abstract}

JEL Codes: D63, F02, J53

\section{Keywords:}

Decent work, gender, global value networks, labour rights, occupational safety, sexual harassment, trade unions, vulnerable workers

\section{Introduction}

The outsourcing of production by firms in the global 'North' 2 to suppliers in the global South has led to a much-remarked growth in female employment in manufacturing industry, in services and more recently, in agribusiness (Pearson, 2007; Barrientos, 2014). Despite a number of studies of gender within global value chains (GVCs), sexual harassment at work 
remains under-researched in 'Southern' contexts. Studies that do raise the issue, find it to be widespread (Christian et al., 2013; Brahic and Jacobs, 2013; ILO, 2014).

Based on research carried out by the NGO Women Working Worldwide (WWW) ${ }^{3}$ and its partners in Ethiopia, Kenya, Tanzania and Uganda, this article presents a case study of sexual harassment in the cut-flower and horticulture industries. It argues that the structure of work relations in the value chain as well as existing gender subordination, foster sexual harassment. This analysis is important in informing strategies to tackle harassment.

The article first presents relevant background before discussing the case study and findings. The next section outlines the cut-flower sector in east Africa, followed by a review of relevant literature identifying the scale and theorising the social bases of sexual harassment. It then introduces WWW's work and the methodology employed in the action research agenda in which the case study research was embedded. The subsequent findings and discussion sections are organised around three central research questions. First, what is the prevalence of sexual harassment on agribusiness farms and how do informants define harassment? Secondly, how do conditions in the industry as well as hierarchical gender relations, foster sexual harassment? Last, what are the most effective strategies and policies to combat harassment?

\section{Women in value chains and the east African cut-flower sector}

Discussion of employment in GVCs has outlined both positive and negative aspects (Dejardin 2008). Paid work assists women to support themselves and families, as well as increasing their autonomy and bargaining power at home (e.g. Doss, 2011). Women are sometimes able to enter high quality, skilled employment with better prospects than 'typical' women's work on microfarms or in petty trading. Less optimistic assessments, however, have been common, from Elson and Pearson's early (1981) intervention to the present. Much of the work pays little, since women workers are clustered at the lower ends of value chains. Work conditions are often poor, with extremely long hours added on to the usual female responsibility for domestic labour and childcare. Rather than work becoming stable and higher-skilled, global outsourcing often means low-skilled, highly unstable and casualised work (Pearson, 2007). This situation reflects perceptions of the lesser value of women's work, and of women as embodied beings. As Barrientos (2014) argues, economic 'upgrading' (to activities at higher ends of value chains) is not always accompanied by 'social upgrading' (of pay and working conditions). ${ }^{4}$ Sexual harassment constitutes an additional risk in women's paid employment.

In many societies, women working outside the home are morally suspect per se: women's labouring bodies (and those of some men) may be seen as literally 'out of place' in formal employment, where they are away from the control of husbands or fathers (Jacobs, 2010). This is not to argue that women move from 'safety' at home to the 'danger' of paid work: they may already face intimate violence at home. However, entry into paid work does often present a new situation in which unrelated males are in authority. Conditions in many GVCs foster coercive labour relations. At the same time, the global placement of the value chain, the 'branding' and marketing undertaken by 'Northern' firms and the organising and mobilising activities of unions, also present opportunities for regulation.

\section{The Horticultural and cut-flower sectors in east Africa}

The horticultural export sector in east Africa has developed since external investors were attracted in the 1980s. The industries in the current research mainly produce cut flowers and vegetables. Kenya is now the fourth largest flower exporter globally (Barrientos, 2014) but the cut-flower and horticulture industries must compete, particularly with Latin America, India, China and Indonesia, to survive global fluctuations of demand and costs.

Cheap labour is east Africa's key advantage (Labuschane, 2008) and the workforce on horticulture farms is predominantly female (Dejardin, 2008). Roles are gendered, and 
hierarchically organised; women remain underrepresented in management. Women work in greenhouses and in fields, but also in the better-paid packhouses (Barrientos, 2014). Many lack contracts, or these are temporary, seasonal or nominally part-time. In the late $1990 \mathrm{~s}$ in Tanzania, for instance, farms producing fruit, vegetables and flowers employed $86 \%$ casual labour (WWW, 2007). Low wages are endemic, and most workers find it hard to meet basic needs. Work can be dangerous, involving heavy use of pesticides in enclosed spaces (Brahic et al., 2011). The global economic crisis as well as factors such as rising transport costs, have increased pressure for costs to be passed on to workers; just-in-time production requires workers to 'absorb' fluctuations in prices and demand. The difficult conditions common in the industry also underpin harassment.

\section{Literature review: conceptualising and addressing sexual harassment}

Literature on sexual harassment has emphasised its systematic nature: it is not simply private but often takes place throughout organisations, usually targeting women. Nor is it simply 'sexual', but is often a tool in coercive power relations. Since MacKinnon (1979) first articulated the issue, two broad approaches to sexual harassment have emerged: a) those conceptualising harassment as an aspect of wider violence against women; and b) those focusing on policies, procedures and protocols to address it. Although not contradictory, these approaches offer somewhat different perspectives, resulting in a diverse literature.. This section focusses on definitions and incidence; on theories of structural and wider factors precipitating harassment, and on some 'Southern' studies.

\section{Naming and defining sexual harassment}

In the North, sexual harassment was identified only from the late 1970s. MacKinnon noted the dearth of vocabulary to frame experience: '...lacking a term to express sexual harassment, it becomes unspeakable' (1979). Following MacKinnon's work, harassment came to be defined as an exercise of power and to be theorised as an aspect of wider male domination.

In the USA, the Supreme Court recognised harassment in a hostile work environment as well as quid pro quo behaviour (see below) as infringements of the 1964 Civil Rights Act in Meritor vs. Vinson (1986). The ILO defines sexual harassment as 'sex-based behaviour that is unwelcome and offensive to its recipient.' It may take two forms:

i) Quid Pro Quo: when a job benefit - such as a pay rise, a promotion, or continued employment -becomes conditional on some form of sexual behaviour (often, between superior and subordinate); and

ii) Hostile Working Environment: in which the conduct creates conditions intimidating or humiliating for the victim (often between co-workers) (ILO 2013).

Harassing behaviours range from whistling and sexually suggestive gestures to comments about appearance, unwanted proposals and invitations to go on dates and sexual taunts. Physical harassment includes touching, physical violence, unnecessarily close proximity and rape. McDonald (2012) notes that while there is no universal definition of harassment, most legal statutes contain similar elements such as descriptions of conduct that has the purpose or effect of being intimidating, hostile, degrading humiliating or offensive. Quid Pro Quo behaviour is a common feature. Moving on from these understandings, the concept has been applied more broadly to gendered behaviour that appears to have little to do with sex but much to do with forms of masculinity prone to intimidating or belittling (Berdhal, 2007; Connell, 2009).

\section{Estimates of incidence}

The reported incidence of harassment is often intertwined with definitions: naming a 
phenomenon both helps to construct it and affects perceptions of it. For instance, Wilkerson (1999, cited in O'Leary-Kelly 2009) found training on harassment had a positive effect on labelling of sexual coercion. Welsh's (1999) review noted extreme variation in reported incidence, reflecting measurement issues as well as differing perceptions. The study of incidence of sexual harassment is also hampered due to fear of reprisal and concern about reputation.

A number of 'Northern' studies have attempted estimates of the extent of sexual harassment. These have yielded variable percentages -from 23-55\% - of women affected (for a selection, see Gruber, 1990; ILO, 2014; Maypole and Skaine, 1982; Uggen and Blackstone, 2014). Some studies carried out in the global South also indicate incidence. In Siddiqui's (2003) Bangladeshi study, 35\% of women had experienced sexual expletives and/or propositions at work; $14 \%$ were physically harassed and $16 \%$ 'had heard' of rape in their own factory. Pantaleón (2003) in the Dominican Republic found that $41 \%$ of women factory workers reported harassment and a 2007 Hong Kong survey found that $25 \%$ of female workers experienced harassment (ILO, 2014). It is notable that both 'Northern' and 'Southern' studies have found that a minority of men - particularly GBTQ men or men perceived as 'effeminate' - also suffer sexual harassment at work (see Uggen and Blackstone, 2004). Thus, in both the global 'North' and 'South', sexual harassment is found to be widespread, especially within factories and supply chains.

\section{'Structural' factors and vulnerability to sexual harassment}

Perspectives that employ an organisational explanation of 'antecedents' (precipitating factors) of sexual harassment, usually emphasise at least one of three features: workplace cultures (including toleration of harassment); gendered work groups; and differential power within organisations (McDonald, 2012). Other studies stress structural relations and beliefs about masculinity and femininity at work, as key to understanding sexual harassment. Early on, Schneider (1982) noted compulsory heterosexuality at work as an organising frame. The men most likely to be harassed are young, gay, and/or ethnic minority members (ILO 2014). Much sociological research on gender and work has emphasised broader social and structural factors: 'Organisational forms structure and are themselves structured by gender' (Witz and Savage, 1992: 8). Socially legitimated and gendered power differentials also contribute (Berdhal, 2007; Cockburn, 1991): thus, women who work for male supervisors are likely to be subjected to sexual harassment (McCann, 2005). Adult women are most likely to be harassed and to experience physically coercive forms (Uggen and Blackstone, 2004), but research also emphasises how attributes such as ethnicity or marriage status may mediate femaleness.

Low occupational status is identified as an important factor. As Siddiqui (2003: 7) points out 'The more precarious is a worker's job, the more likely she is to be harassed'. In the USA, O'Leary-Kelly (2009) concludes that the incidence of harassment is higher amongst blue-collar women workers.. ILO findings (in McCann, 2005) point towards women who are financially dependent as being at most risk. Thus, single, divorced separated, widowed or never-married women (European Commission, 1999) are particular targets. A key finding is that casual and informal sector workers are picked out. Rogers and Henson's USA research (1997) and Takao's Japanese research (2001, cited in McDonald, 2012) on temporary workers also confirmed that such workers were liable to harassment. This is also true in developing countries (McCann, 2005). Hence, organisational power inequalities 'set the stage' for harassment (Rospenda et al., 1997).

Thus, much progress has been made in the study of sexual harassment — particularly, concerning incidence and definitions, and structural framing factors. Most research remains firmly planted in the North, but some studies have been carried out in Southern contexts 


\section{The ILO, and some 'Southern' studies}

The ILO (International Labor Organisation) has been an important 'mover' in research on sexual harassment. Siddiqui notes,

....[I]n 1979, the CEDAW [Convention on the Elimination of All forms of Discrimination against Women] ... included sexual harassment in its definition of violence. In 1992, the International Confederation of Trade Unions adopted a resolution recognising sexual harassment as a legitimate trade union issue` (2003: 3).

If the ILO's interventions have been important, they also have limitations. ILO Convention 111 prohibits gender discrimination but does not specifically cite sexual harassment or freedom from violence at work as a core labour right (Pantaleón, 2003). Nonetheless, the ILO began enacting legal instruments from 1985 and has commissioned several studies as well as activist measures such as anti-harassment training in Jordan (ILO, 2013). Attention to harassment has increased greatly since 2005, and the ITUC $3^{\text {rd }}$ Congress mentions improved regulations in several countries, especially within South Asia (ITUC, 2014).

Separately, mention of harassment exists within some of the labour studies literature relating to GVCs, particularly regarding to production line factory work (e.g. Hewamanne, 2008). Research in the global 'South' emphasises that violence against women tends to flow from the home and street to the workplace (Pantaleón, 2003) - or as Liz Kelly termed it, there is a 'continuum of violence' from domestic to public and national levels (Kelly, 1988). Work on sexual harassment in Latin America has stemmed particularly from this perspective rather than more institutional approaches found elsewhere (McCann, 2005). Women brought into formal production gain a measure of independence; however, this may be seen as infringing existing gendered norms. Removed from the 'protection' of home, women may suffer unwanted attention from managers and sometimes, co-workers (Friedmann, 1986). In global supply chains, incidence of gendered coercion may intensify (Dejardin, 2008) and coercion can take sexualised forms.

Relatively little African work on sexual harassment exists. However, an International Labor Rights Fund 2002 study found that $90 \%$ of women workers in Kenyan export industry including plantation work - had suffered sexual harassment although 95\% never reported this (ILRF, 2002). A study by the German Development Assistance Agency (GIZ, 2014) of Tanzanian public services, indicated high harassment levels. Few studies exist in agriculture, (but see Dominguez [1998] in the USA). Beyond Africa, an ILO study of Sri Lankan plantation workers (Wijayatilake and Zackariya, 2001) indicated that women suffered harassment but lacked confidence that the union would take up abuses. Overall, sexual harassment within work settings in the global South remains little-researched. The study we introduce below, thus contributes to literature, especially in agribusiness sectors.

\section{Contextualisation of the study and research methods $W W W$ and its partners}

WWW and its East African partners have conducted research and interventions on horticulture farms since 2005. This section outlines this work and explains how the focus on sexual harassment arose. WWW has four partners in the present research. These are: (in Ethiopia), the National Federation of Farm, Plantation, Fishery and Agro-Industry Trade UnionsNFFPFATU; (in Kenya) Workers' Rights Watch - WRW; (in Tanzania), TPAWU or the Tanzania Plantation and Agriculture Workers Union and (in Uganda), the Uganda Workers' Education Association - UWEA. The partners have also organised into an 'umbrella' advocacy organisation, GHOWERN: the Global Horticultural Workers' and Environmental Rights Network, in order to share effective practice. 
The current research on sexual harassment, funded by HIVOS (Humanist Institute for Cooperation) in the Netherlands, developed from two previous projects, running between 20052011. These focussed on casualisation and associated conditions on farms such as low pay, dangerous conditions; provision of protective equipment, and lack of enforcement of rights such as maternity pay. In particular, WWW's interventions have helped to reduce casualisation. For instance, in Ethiopia, 50\% of farmworkers had been converted to permanent contracts in 2010 (Marix Evans, 2011). The projects focussed on building women's presence within unions and through instituting Collective Bargaining Agreements (CBAs) (Brahic et al. 2011) and codified anti-harassment policies. Such codification occurred, for instance, in Uganda and Kenya, in all or nearly all farms in the study, although in Tanzania and Ethiopia, far fewer farms' CBAs (25\%-31\%) included harassment policies.

Ledwith and Colgan (2002) note that traditional trade unionism is characterised by patriarchal working-class organisation; this has been challenged both externally by forces of global restructuring (as in the horticultural industry) and internally, by groups of marginalised workers. Using their categorisation, autonomy and separate organisation was one of the strategies used by WWW. Thus, Women Workers' Committees (WWCs) - that is, separate structures ${ }^{5}$ - have also proved important spaces for discussion (Brahic and Jacobs, 2013): the current research was carried out because workers highlighted sexual harassment as a (or at times, the) issue in their working lives (GHOWERN, 2013). Thus, harassment, from being a hidden and private 'shame', began to become an articulated and shared concern. It became evident that harassment might be endemic; that its impacts might be serious, and that it could prove a problem difficult to address. This article thus focuses on baseline research carried out in Ethiopia, Kenya, Tanzania and Uganda in autumn, 2012.

\section{Methods and the sample}

The aim of the research, as noted, was to gain understanding of the forms and frequencies of sexual harassment; and to identify factors that allow it to persist and ways forward through effective policies. Interviews were carried out with workers (predominantly, women); with trade union officials and with farm management in the four countries. Action research is central to WWW's ethos, and holds potential to give space to the most marginalised, including those at the bottom of global value chains. Typically, action research combines research, education and advocacy (Hale, 1996) so that evidence is used as a mobilising tool. In the present context, action research entailed collaborative work done by partner organisations. Each partner devised samples that they saw were most practical for the organisations and farms concerned. Thus, there were different approaches to sampling, including sample sizes and stratification, affecting comparability between research sites.

Because of its prime objective to alter conditions 'on the ground', the project's emphases differed somewhat between countries. Thus, WRW in Kenya wanted to ascertain the effectiveness of the policies formulated and beginning to be put into practice. By contrast, in Ethiopia, policy formulation was at an early stage. Aware that this was the first piece of research on sexual harassment within the Ethiopian horticulture sector, NFFPFATU concentrated on ascertaining definitions and perceptions of harassment; its extent; the forms it took and the likely targets.

Owing to these factors, the sample is not representative. Nevertheless, the study includes a relatively large number of informants from different groups or 'stakeholders' and covers 62 farms: 16 in Ethiopia; 15 in Kenya; 20 in Tanzania; 11 in Uganda. Women workers formed the largest group of informants although male workers were included in some countries. In Ethiopia, 160 workers were surveyed, as well another 32 women workers interviewed in six focus groups. The samples were smaller elsewhere, with 40 workers interviewed in Kenya; 22 women in Uganda and 32 in Tanzania, making a total of 254 respondents (or 286 including the 
focus groups). Some 94 trade union representatives were interviewed (32 in Ethiopia; 24 in Tanzania; 38 in Uganda). A number of managers were also interviewed: 16 HR personnel in Ethiopia; 20 in Tanzania plus another three local government officials; and 27 managers in Uganda.

Although many studies on harassment measure incidence using the Sexual Experiences Questionnaire developed by Fitzgerald et al. (1988), WWW's partners have used the ILO's definition. This was most straightforward to operationalise with limited resources. Questions to informants concerned demographic information, as well as definitions, perceptions and incidence of sexual harassment; factors causing harassment; knowledge of any anti-sexual harassment policies, and suggestions to improve procedures and policies. ${ }^{6}$

\section{Discussion of findings}

This section analyses findings of the research. It first discusses definitions and prevalence of sexual harassment before exploring linked structural and precipitating factors. The third section examines policies and initiatives against harassment.

Before discussing the research data, it should be noted that different legislation on sexual harassment exists within the four countries. The Ethiopian legal system does not name sexual harassment as a criminal offence except in cases of rape or abduction, although the Constitution (1995) guarantees women full equality (Mariam, 2011). In Tanzania, harassment is covered under the country's criminal code (ILO 2014). However, implementation is in practice very limited (GIZ, 2014). The Ugandan government developed draft Employment (Sexual Harassment) Regulations as part of the framework of the 2006 Employment Act. These require employers to disseminate a sexual harassment policy to all employees. In Kenya, Section 21(2) of the Public Officer Ethics Act and Employment Act section 6 specifies behaviour considered as harassment. This Section also mandates that every employer of 20 or more workers sets up a policy. A separate Sexual Offences Act (2006) allows a victim of sexual harassment to press charges and places special duties of prevention on those in authority (MyWage Kenya, 2014).

\section{Definitions, Perceptions and Prevalence}

The studies asked how informants defined and perceived sexual harassment, as well as attempting to establish incidence within the farms. Perceptions of what constituted harassment varied widely among workers, as illustrated by a comparison of Ethiopian and Kenyan findings. For instance, on Ethiopian farms, 61 (38\%) of workers had never heard the term 'sexual harassment'. The majority of women felt that this only covered incidents of rape at work and some suggested that women themselves provoke harassment and sexual violence. In Uganda, similarly - despite much more robust policies on paper - sexual jokes, gestures and sexual touching were still considered 'normal' by many women workers. These views contrast with those of many respondents in Kenya. It might be of relevance that gender relations have been the subject of campaigns within Kenyan civil society and political movements, including an anti-harassment campaign in 2000-2003. Nonetheless, levels of awareness were uneven. Definitions or conceptions of harassment tended to be wider where policies were already in place on farms. Workers who had attended information and awareness-raising sessions, not surprisingly, demonstrated a greater tendency to label unwanted sexualised behaviour as harassing. This supports findings on the impact of training on perceptions (Wilkerson, 1999; Lonsway et al, 2008).

Research findings highlighted gaps in union representatives' knowledge. In Kenya, all representatives agreed that pressure to have sex, Quid Pro Quo behaviour and touching were sexual harassment, but less than $15 \%$ thought that pressure to go on dates, sexual innuendo and gestures were problematic. In Uganda and Ethiopia, some representatives felt that women's own behaviour (for example failure to dress 'modestly' enough) caused harassment. Apart from 
lack of experience due to staff turnover, more persistent areas of concern emerged, particularly as not all union leaders saw anti-sexual harassment actions as important.

The level of knowledge amongst management varied greatly across the sector, and most managers interviewed had limited experience in dealing with harassment complaints. Workers indicated that management tended to downplay its extent, either by treating harassment as a private issue or by portraying such behaviour as 'part of every woman's life'. Managers tended to feel that workers themselves were a factor in the persistence of sexual harassment in the workplace. The impoverished economic situation of many women workers and the status of single parenthood - many are lone mothers - were considered to put women at risk. Thus, a range of definitions and perceptions were revealed, ranging from managerial indifference (although with exceptions) to lack of knowledge among some trade unionists, to fear among workers. These can be mutually reinforcing and point to the need to raise awareness as well as to develop a strong legal basis to challenge harassment.

No official data on the prevalence of sexual harassment exist in any of the countries or farms researched. The preliminary data on incidence collected on farms, however, imply that harassment is widespread across the four countries. Although the present research focussed on women workers, it should be noted that men could also be objects of harassment; instances of men being harassed (in nearly all cases, by female managers) were also reported (WWW, 2013). Very high percentages of women workers, however, had experienced harassment on farms or knew someone else who had. In Ethiopia, of the 160 women sampled, 137 said they had experienced some form of harassment themselves (GHOWERN, 2013: 14). In Tanzania, $89 \%$ of women workers across the 20 farms had personally witnessed one or more incidents, mainly perpetrated by managers (GHOWERN, 2013). In Kenya, 90\% of those interviewed rated sexual harassment as the most difficult problem experienced by women in the cut flower sector. Forty percent of Kenyan respondents had experienced offensive sexual jokes and comments; $24 \%$ experienced unwanted touching and 18\% had had threats of reprisal for not responding to sexual advances. Another $2 \%$ reported sexual assaults. Harassment occurred both at work and outside - on transport, in towns and in the countryside - and this varied little between countries. This spatial 'spread' is similar to Saddiqui's observations about sites of violence in Bangladesh (Siddiqui, 2003).

\section{Structural and precipitating factors}

The studies asked informants who or which groups were most likely to experience sexual harassment, as well as what factors precipitated or contributed to harassment.

\section{Targets and perpetuators}

The most common targets of harassment, as noted, were individuals - especially women in insecure and low-paid positions. As one Ethiopian WWC representative noted,

Temporary grading workers are more vulnerable; they face more harassment as they are not permanent employees of the farm, do not readily complain and remain in fear of losing their job. (GHOWERN, 2013)

Workers at greatest risk were those in junior and routine jobs such as greenhouse work and production workers. Additionally, women on short-term and daily contracts were particularly vulnerable. This echoes Rogers and Henson's (1997) findings that temporary and casual workers are likely to be targets. Men in managerial or supervisory positions were most frequently cited as perpetrators. Women also reported cases of harassment by union leaders and co-workers: for instance, in Ethiopia, $22 \%$ of incidents involved male co-workers. These findings were fairly constant across the countries and serve to underline harassment's basis in power as well as production relationships. They also emphasise that WWW and partners' work 
to combat casualised labour in agribusiness estates is itself an effective measure (Brahic and Jacobs, 2013).

\section{Factors leading to sexual harassment}

The country surveys all asked which factors might lead to harassment: differences between country samples were notable. Explanations in Ethiopia concentrated on social and cultural features; those in Uganda were more firmly 'material' in tone, and responses in Kenya concentrated both on material causations and policy deficiencies. Socio-cultural factors included cultures of silence; shame and denial; local norms enjoining that women should be quiet and uncomplaining; low female literacy levels, and perceptions that women workers themselves were to blame. Punitive reactions were widely feared from male partners and communities if sexual harassment was reported, since the women concerned would be seen as tainted or morally suspect. Material factors were also seen as creating vulnerability to targeting. These included low wages and long working hours; housing policy (sometimes linked to farm employment) and job insecurity. Thirdly, policies and procedures (or, their lack) were cited as key. These included discriminatory employment policy; mechanisms of recruitment and promotion often being open to sexual harassment; lack of privacy in reporting as well as the time-consuming nature of such reporting. Where policies and procedures were stronger, responses were more likely to stress policy rather than 'cultural' features. Anxiety about 'double victimisation' if a complaint failed was also common. McDonald (2012) notes that such fears are not unfounded, as reporting harassment can worsen outcomes for the target.

\section{Policies and strategies against harassment}

An important focus of this research was to explore policies and procedures to ascertain what might be effective. WWW and its partners have worked to systematise policies and to develop interlinked strategies implementing anti-harassment provisions. A general finding, however, was that policies were not strongly enforced. In Ethiopia, few systematic policies had been enacted: only $9 \%$ of women who said they had experienced harassment had reported this to someone in authority and few knew of a department on farms dealing with such matters. Thus, women were thrown back on 'coping' mechanisms such as avoiding the perpetrator if possible or asking for a transfer. In Kenya, responses to complaints mainly involved training and awareness-raising. A union representative noted, 'The biggest challenge in efforts to deal with sexual harassment is weak enforcement' (WWW, 2013). Complaints are often dealt with through transferring the complainant to another department or else transferring the perpetrator, although in $4 \%$ of cases, a harasser was dismissed. In Uganda, workers complained that there was no formal way to record complaints. Ugandan WWC members also noted that educational materials translated into local languages (even widely-spoken ones), were often unavailable; therefore, in practice policies could not be disseminated. In Tanzania, 90\% of managers said that although policies existed, they had not been communicated to workers or supervisors (WWW, 2013). In general, anti-sexual harassment policies and reporting mechanisms tended to be weak: there exists an urgent need for robust policies.

\section{Areas of good practice:}

Whilst work clearly remains to be done, a number of areas of good and positive practice exist, as discussed below.

\section{Collective Bargaining Agreements}

Inclusion of sexual harassment sanctions within Collective Bargaining Agreements is one of the most important initiatives, as noted. For instance, in one Ugandan case in which a woman was dismissed when she complained of harassment, the existence of the CBA assisted UWEA 
and the union to ensure her reinstatement.

\section{Formation of Women Workers' Committees}

The formation of WWCs within and alongside unions is, as discussed, itself one of the reasons that sexual harassment has been taken up as a labour issue on the farms. In three countries, WWCs have been formed under the guidance of WWW and partners and WWCs are often tasked with handling harassment. In Tanzania, WWCs were formed on most project farms and handled harassment cases (GHOWERN, 2013). In Uganda, WWCs organise meetings on harassment, and report cases to management as well as keeping notes on incidents. It was noted that 'women have trust where they elect their own WWC' (WWW, 2013: 25; see also below). Testimony on WWCs also emphasised the need for more training on procedures, particularly the need for WWC members to observe confidentiality. A number of informants mentioned ways of empowering WWCs to act effectively, such as being given sufficient time to meet and to work together, and gaining more formal oversight responsibilities.

\section{Training and awareness-raising}

One of the most widespread aspects of good practice was awareness raising. WWW and partners have presented the existence of harassment as an issue affecting profitability in an effort to overcome managerial reluctance to allow training. Training often takes place as part of formal instruction either to managers or workers. In Kenya, the main policy response involved education, and in Tanzania, TPAWU and affiliates had helped to train 4,215 workers by 2013 (GHOWERN, 2013). In Uganda, anti-harassment training was sometimes part of induction training on farms. One Ugandan worker commented: 'Male supervisors now don't touch the body parts of their subordinates. This change has happened ... after the anti-sexual harassment policy' (ibid). Instances of 'innovative' strategies were noted. In Kenya, workers mentioned a successful initiative in which supervisors went 'from worker to worker' in each department explaining what sexual harassment is and consequences for perpetrators. In Uganda, similarly, WWC members sometimes went from greenhouse to greenhouse to discuss harassment and remedial policies with workers. Informal awareness-raising is also important, and takes place when women or male targets discuss the harassment in everyday situations, discussions and confidences. Informal awareness-raising was reported especially in Ethiopia, perhaps in place of formal procedures.

\section{Sanctions against perpetrators}

Fear of victimisation was voiced in all countries, especially among women in very low-paid and low 'status' positions and lack of action was common. This in turn affected confidence to report sexual harassment. As discussed, where perpetrators were disciplined in some way, the most common strategy was simply to move him/her to another department. Particularly where the accused was a manager, this was seen as ineffective. Women workers and trade unionists from all countries stressed the need to hold perpetrators to account, to suspend alleged offenders during investigation and generally to systematise policies. The need for 'punishment' was sometimes mentioned (GHOWERN, 2013). A notable event in Uganda was a widespread official strike culminating in the dismissal of two managers. The strike meant that the Dutch company had to take notice of both threats to profits and to its reputation. This became an impetus to develop measures against sexual harassment within company farms (WWW, 2013).

On four Ugandan farms, such systemisation of policy was developing. Disciplinary committees had been established, with WWC representatives and shop stewards investigating cases and meeting with complainants and the accused. Findings are subsequently discussed with HR managers, and appropriate action decided jointly by the committee and HR. Where 
effective action does take place, this becomes well-known, builds confidence in procedures and increases reporting of harassment.

\section{Women and leadership}

Women, as the most likely targets of sexual harassment, might be seen as most inclined to implement anti-sexual harassment policies. This is the case to some extent but contradictions also exist. One is that women can also sexually harass, as noted. Another is that people in leadership positions can identify with hierarchies, and female union leaders may wish to be accepted within wider union structures. Women managers likewise may conform to managerial imperatives. Nonetheless, some successful outcomes exist as a result of supporting female leadership.

Encouragement of women into positions of leadership within unions has been part of WWW's strategy to build women's capacity to act in face of widespread harassment (Brahic and Jacobs, 2013). This is not always straightforward since these may not be welcomed by union leaders and other cadres. However, WWCs have sometimes been able to 'nurture' women as leaders, and some have been able to take on wider leadership roles. A Kenyan worker said: 'where women are shop stewards, workers are more likely to report sexual harassment.' In one Tanzanian farm, women leaders on the WWC followed up a case closely and a manager was sacked. In this research there were a number of mentions across countries of women unionists being eager to formulate and enforce anti-sexual harassment policies. Encouragement of women's trade union leadership was thus seen to be a fruitful strategy.

Women managers evidently inhabit positions that differ from female trade unionists in class and status, and their job roles and interests may contradict and conflict with those of workers. Female managers may be under pressure not to report other managers as harassers. Women managers may also have an interest in moving up the organisational hierarchy, which can involve anti-labour actions. For example in Uganda, there were instances of management dissolving the union WWCs and instituting their own committees under management direction. It was reported that the new 'gender committees' were less effective - indicating that separate structures need to be anchored in the labour movement. Across countries, workers sometimes felt that HR managers either lacked time or commitment to deal with harassment.

Nonetheless, bringing women managers (in HR or in supervisory positions) 'into' antisexual harassment strategies has had some success. These strategies have been particularly evident in Tanzania - where women HR managers on some farms have been active in pursuing complaints - as well as in Uganda. Several initiatives were taken in the Ugandan farms, including the one where the strike occurred. One involved hiring more women HR managers: on two farms, nearly one-third of managers are women. On these farms, promotions and recruitment committees also have a substantial minority of women managers. On several farms, recruitment of workers at the farm gate now consists of one woman and one male HR manager, and this has lessened Quid Pro Quo harassment. Lastly, male supervisors now rarely monitor the presence of workers and so fewer complaints exist about practices such as unfairly marking women as absent, or arbitrary cancellation of work days. (GHOWERN, 2013).

\section{Conclusion}

This article has offered a contribution to the relatively scant literature on sexual harassment of women in agribusiness and within African contexts. The research here indicates that sexual harassment is widespread on farms in the study and that female temporary and casualised workers are the most likely - but by no means the only - targets of harassment. Sexual harassment is framed by arduous working environments: conditions including low pay, linking of housing with employment and dangerous working conditions, help to foster harassment. So 
too, do gendered job hierarchies, views that harassment is part of 'women's lot' at work, and cultures that blame women. Thus, conditions in this GVC coupled with existing gender subordination frame and encourage sexual harassment.

The study has also outlined some successes in combating sexual harassment: action research has helped to give 'voice' to marginalised workers. The existence of Women Workers' Committees (WWCs) and the strengthening of women's leadership, especially in trade unions, have begun to turn private anger and shame into collective grievances. The strengthening of workers' position - for example. through campaigns for higher pay and against casualisation - have also begun to undermine the material bases of harassment.

Nonetheless, the study also shows that formulation and implementation of policies have proved challenging, even where anti-harassment policies are 'in place' on paper. One reason for this is simply that strategies are at an early stage. However, there are indications of resistance arising at different levels, including normalisation of harassing practices, managerial indifference and at times, lack of concern about sexual harassment within unions. This research took place because of the key importance of the issue of sexual harassment to women workers, as articulated within WWCs. Lack of implementation of policy is a 'signal' that women's subordination at work continues and is reinforced through harassment.

Workers in this study were asked for their suggestions for change. These were many, but included that workers need to be involved in policy formulation, as they best understand the risks involved. Secondly, the importance was stressed of sector-wide policies against sexual harassment to be used by all farms to avoid piecemeal policies. Thus, these grassroots suggestions focus on the need for wider, systematic and more monitored policies.

Although work conditions within GVCs are often very difficult, their transnational aspect can also provide opportunities. As Briskin (2002) stresses, there exists potential for trade unions to raise the global potential for international feminist alliances. Industries with transnational links are sometimes more open to regulation and to transnational organisation. ${ }^{7}$ Workers in this study suggested as much, demanding that external auditing be strengthened to verify that farms are compliant with codes rather than paying 'lip service'. Concerns about profitability ${ }^{8}$, reputation and publicity can provide a 'handle' that may mean it is possible for international support groups as well as local labour organisation to pressure to improve working conditions.

Struggles against sexual harassment at work have been broadly, part of movements against violence against women. It is important to build on this, but also to see struggles as part of gendered and egalitarian labour rights: women as well as men have the right to work without sexual violence and coercion. WWW and east African partners' work has indicated that it is possible to organise around sexual harassment. This in itself is an achievement, as well as a step towards building effective policies.

The ability to refer to wider national and international codes has been crucial in putting the issue of harassment 'on the agenda'; external and transnational organisations can provide useful resources. However, these cannot and should not take the place of local actors in formulating procedures and strategy on an issue that many participating in this research, saw as key. Action against sexual harassment requires both understanding of the phenomenon as a core labour issue and campaigns at local and transnational levels.

\section{Funding}

HIVOS (Humanistisch Instituut voor Ontwikkelingssamenwerking) /: International Humanist Institute for Cooperation with Developing Countries, the Hague, the Netherlands 


\section{References}

Barrientos SW (2014) Gender and Global Value Chains: Challenges of Economic and Social Upgrading in Agri-Food. European University Institute Working Paper, Florence. Available at: http://cadmus.eui.eu/bitstream/handle/1814/32897/RSCAS_2014_96.pdf?sequence=1 (accessed 9 June 2015).

Berdhal J (2007) Harassment based on Sex: Protecting social status in the context of gender hierarchy. Academy of Management Review 32(2): 641-858.

Brahic B and Jacobs S (2013) Empowering women: A labour rights-based approach. Journal of Agricultural and Environmental Ethics 26(3): 601-619.

Brahic B, Olaiya MM, Jacobs S with English R (2011) Organising Women in the Agribusiness Sector: Case studies from East Africa. Labour, Capital and Society 44(1): 70-97.

Briskin L (2002) The equality project in Canadian trade unions: Confronting the challenge of restructuring and globalisation. In: Colgan, F. and S. Ledwith (eds) Gender and Diversity in Trade Unions. London: Routledge, pp. 28-47.

Christian M, Evers B and Barrientos SW (2013) Women in value chains: Making a difference. Capturing the Gains Briefing paper no. 6.3, February. Manchester: University of Manchester.

Cockburn C (1991) In the Way of Women. Ithaca, NY: Cornell University Press.

Connell R (2009) Gender: In World Perspective. $2^{\text {nd }}$ edition., Cambridge: Polity.

Dejardin AK (2008) Gender dimensions of globalization. Geneva: ILO. Available at: www.ilo.org/wcmsp5/groups/public/@dgreports/@integration/documents/meetingdocument/ wcms_100856.pdf (accessed 30 May 2015).

Domínguez M (1998) Sex discrimination and sexual harassment in agricultural Labor. American University Journal of Gender and Law 231: 231-259.

Doss C (2011) Intrahousehold bargaining and resource allocation in developing countries. World Development Report 2012 Briefing Paper, Washington, DC: World Bank. Available at: http://siteresources.worldbank.org/INTWDR2012/Resources/77781051299699968583/7786210-1322671773271/Doss-Intrahh-bargaining.pdf (accessed 13 June 2015)

Elson D and Pearson R (1981) Nimble fingers make cheap workers: An analysis of women's employment in third world export manufacturing. Feminist Review 7: 87-107.

Fitzgerald L, Shullman S, Bailey N, Richards M, Swecker J, Gold Y, Omerod M and Weitzman M (1988) The incidence and dimensions of sexual harassment in academia and the workplace. Journal of Vocational Behaviour 32(2): 152-75.

Friedmann H (1986) Patriarchal commodity production. Social Analysis 20: 47-55.

GIZ (German International Cooperation) / Baumgarten I (2014) Sexual harassment and gender-based violence in the public sector workplace in Tanzania mainland. Final study report. Available at:

www.tgpsh.or.tz/fileadmin/documents/News/Report_Sexual_Harassment_in_Public_Sector_ Tanzania-June_2014.pdf (accessed 16 October 2014).

GHOWERN (Global Horticultural Workers' and Environmental Rights Network) (2013) Best practices for combating sexual harassment at the workplace in the horticulture industry in the East African Region. Report. Kampala, unpublished.

Gruber J (1990) Methodological problems and policy implications in sexual harassment research. Population Research and Policy Review 9(3): 235-54.

Hewamanne S (2008) Stitching Identities in a Free Trade Zone: Gender and Politics in Sri Lanka. Philadelphia: University of Pennsylvania Press.

ILO (International Labour Organisation) (2013) Spreading the message on sexual harassment in Jordan's garment factories. July. Available at: www.wurn.com/news/2013/07_13/070113_jordan.htm (accessed 4 June 2014). 
ILO (International Labor Organisation) (2014) Sexual Harassment at Work: Factsheet. Available at: www.ilo.org/wcmsp5/groups/public/---ed_norm/---

declaration/documents/publication/wcms_decl_fs_96_en.pdf_ (accessed 2 June 2014).

International Labor Rights Fund (2002) Violence against women in the workplace in Kenya. Washington, DC. Available at: www.laborrights.org/sites/default/files/publications-andresources/Kenya.pdf (accessed 21 November 2014).

ITUC (International Trade Union Confederation) (2008) Stopping sexual harassment at work: A trade union guide. Brussels. Available at www.ituccsi.org/IMG/pdf/Harcelement_ENG_12pgs_BR.pdf (accessed 12 February 2015).

ITUC (International Trade Union Confederation) (2014) Asia-Pacific report to ITUC $3^{\text {rd }}$ Congress. Available at: www.congress2014..ituc-csi.org (accessed 22 October 2015).

Jacobs S (2010) Gender and Agrarian Reforms. NYC/London: Routledge.

Kelly L (1988) Surviving Sexual Violence. Cambridge: Polity Press.

Kirton G (2007) The Making of Women Trade Unionists. Farnham: Ashgate.

Labuschane L (2008) Flower farming: Kenyan horticulture leads the way. Pesticides 82(2): 6-7.

Ledwith S and Colgan F (2002) Tackling gender, diversity and trade union democracy. In: Colgan, F and Ledwith S (eds) Gender and Diversity in Trade Unions. London: Routledge, pp. 1-27.

Lim S and Cortina L (2005) Interpersonal Mistreatment in the Workplace. Journal of Applied Psychology 90(3): 483-96.

Lonsway K, Cortina L and Magley V (2008) Sexual harassment mythology: Definition, conceptualization and measurement. Sex Roles 58 (9-10): 599-615.

MacKinnon C (1979) Sexual Harassment of Working Women. New Haven CT: Yale University Press. McCann, D (2005) Sexual Harassment at Work: National and International Responses. Geneva: ILO Conditions of Work and Employment Programme. Available at: www.ilo.org/wcmsp5/groups/public/---ed_protect/---protrav/--travail/documents/publication/wcms_travail_pub_2.pdf (accessed 18 March 2015).

McDonald P (2012) Workplace sexual harassment 30 years on: A review of the literature. International Journal of Management Reviews 14(1): 1-17.

Mariam A (2011) Speaking truth on behalf of Ethiopian women. Huffington Post 25 May. Available at: http://www.huffingtonpost.com/alemayehu-g-mariam/speaking-truth-onbehalf_b_635317.html (accessed 20 June 2015).

Marix Evans L with Jack M (2011) Programme Evaluation Report for WWW. November. Manchester, unpublished.

Maypole D (1987) Sexual harassment at work: a review of research and theory. Affilia 2(1): 4-38.

Maypole D and Skaine R (1982) Sexual harassment of blue collar workers. Journal of Sociology and Social Welfare 9(4): 682-695.

My Wage Kenya (2014) Sexual Harassment: what does the law say? Available at: .mywage.org/Kenya/home/labour-laws/fair-treatment-at-work_ (accessed 10 October 2014).

O'Leary-Kelly A, Bowes-Sperry L, Bates A and Lean E (2009) Sexual harassment at work: a decade (plus) of progress. Journal of Management 35(3): 503-536.

Pantaleón L (2003) Sexual harassment in the export processing zones of the Dominican Republic. Fundación Laboral Dominicana. Available at: digitalcommons.ilr.cornell.edu/cgi/viewcontent.cgi?article=1484\&context=globaldocs (accessed 20 June 2014).

Parker J and Foley J (2010) Progress on women's equality within UK and Canadian trade unions: Do women's structures make a difference? Industrial Relations 65(2): 281-301.

Pearson R (2007) Reassessing paid work and women's empowerment. In: Cornwall, A, Harrison C and Whitehead A (eds) Feminisms in Development. London: Zed, pp. 201-213.

Rogers JK and Henson K (1997) 'Hey, why don't you wear a shorter skirt?' Structural vulnerability and the organization of sexual harassment in temporary clerical employment. Gender and Society 11(2): 215-237.

Rospenda K, Richmann J and Nawyn S (1998) Doing power: the confluence of gender, race and class in contrapower sexual harassment. Gender and Society 12(1): 40-60.

Schneider B (1982) Consciousness about sexual harassment among heterosexual and lesbian women workers. Journal of Social Issues 38(4): 75-98. 
Selwyn B (2013) Social upgrading and labour in global production networks: a critique and an alternative conception. Competition and Change 17(1): 75-90.

Siddiqui DM (2003) The Sexual harassment of industrial workers. Dhaka. CPD-UNFPA Paper. Available at: www.cpd.org.bd/pub-attach/unfpa26.pdf (accessed 17 June 2014).

Takao S (2001) Increasingly less equal. Japan Quarterly 48(3): 24-30.

UWEA (Ugandan Workers' Education Association) (2010) Draft Action Research Report on Progress of Working Conditions in Ugandan Commercial Horticultural Farms. Kampala: unpublished.

Uggen C and Blackstone A (2004) Sexual harassment as a gendered expression of power. American Sociological Review 69(1): 64-92.

Welsh S (1999) Gender and sexual harassment. Annual Review of Sociology 25: 169-190.

Wijayatilake K and Zackariya F (2001) Sexual harassment at work: Plantation Sector. ILO:

Colombo. Available at: www.actnowsrilanka.org/en/books/142-sexual-harassment-at-workplantation-sector (accessed 12 May 2014).

Wilkerson J (1999) The Impact of job level and prior training on sexual harassment labelling and remedy choice. Journal of Applied Social Psychology 29(8): 1605-23.

Witz A and Savage M (1992) The gender of organizations. In: Savage M. and Witz A (eds) Gender and Bureaucracy. Oxford: Oxford University Press, pp. 3-62.

WWW (Women Working Workldwide) (2007) Promoting Women Workers' Rights in African Horticulture. Manchester: unpublished.

WWW (Women Working Worldwide) (2013) Sexual Harassment: Executive Summary of Research carried out on Selected Horticultural Farms in Ethiopia, Kenya, Tanzania and Uganda. Manchester: unpublished, March.

\section{Biographical Notes:}

Susie Jacobs is a Reader in Comparative Sociology at Manchester Metropolitan University. She has published widely on gender, agrarian reforms and land rights; women's movements, and on 'race; and ethnicity.

Bénédicte Brahic is a Lecturer in Sociology at Manchester Metropolitan University, and previously worked as Research Associate at Women Working Worldwide. She has also conducted research on multilingualism and on transnational family relations.

Marta Medusa Olaiya is Development Officer for Women Working Worldwide.

\section{Endnotes}

\footnotetext{
${ }^{1}$ Thanks to the anonymous reviewers and the editors for their helpful comments and suggestions, and to Graham Trickey for help with editing.

2 The terms 'North' and 'South' are placed in inverted commas as the simple North/South dichotomy has been critiqued in recent debates within the GVC literature. See for example Selwyn (2013).

${ }^{3}$ Founded in 1985, WWW is UK-based; its core mission is to promote women's rights in global value chains (see http://www.women-ww.org).

4 Selwyn (2013) is critical of the 'upgrading' and 'decent work' agendas, arguing that they take insufficient account of labour process theory.

${ }^{5}$ Kirton (2007) and Parker and Foley (2010) also note that forms of separate (women-only) organising have contributed to raising issues of sexual and gender equity within British and Canadian unions.

${ }^{6}$ In addition to the questions asked of all participants, workers were asked about their knowledge of farm-level policies on sexual harassment; perceptions of sexual harassment; likely targets and any incidents on farms as well as about ways to improve anti-sexual harassment procedures. Trade union representatives and shop stewards were
} 
asked about union procedures; about the role of WWCs in combating sexual harassment and about suggestions for policy. Managers and HR personnel were asked about farm-level policies (as were union representatives) and about procedures for policy formulation, including the potential of working with unions.

${ }^{7}$ In Siddiqui's Bangladesh research, the worst conditions and most violent sexual harassment, as reported, were present in the relatively small-scale and local 'bangla' textile factories rather than foreign-owned ones.

${ }^{8} \mathrm{An}$ important and interesting debate exists here, about the advisability of use of 'profitability' as a strategy to change policy. 